\title{
Legal, Social and Economical Grounds Leading to Challenge to Arbitrator in the Jordanian Arbitration Law NO.(31) a Year 2001 and Its Amendments a Year 2018 (Analytical Study)
}

\author{
Dr. Abdel- Kareem Ottallh Al- Karabsheh \\ Al Balqa Applied Univesity, PO box 15 Zip code 19252 Alaan
}

\begin{abstract}
In the arbitration law NO. (31) for a year 2001 and its new amendments for a year 2018 the Jordanian legislator didn't give an adequate attention of challenge to arbitrator, it has generally studied, and this is contrary to the civil trails law which identified the grounds of the judge challenge and stepped him down in detail.Due to my believing in the importance of the grounds of arbitrator challenge that the legislator didn't identified it in details, this is contrary to the grounds of judge to challenge, and in order to achieve the requested integrity from the arbitrator as the judge of state , therefore, This study aimed to know the concept of arbitrator and his appointment rules, and what are the serious grounds to challenge to arbitrator through comparative analytical study shows in studying the legal, social an economical grounds which are considered a ground for requesting a challenge to an arbitrator then re challenge it .This study concluded to a set of results and recommendations hoping this study to be achieved an enrichments to the specialized studies in this fields.
\end{abstract}

Keywords: Arbitration, Arbitrator, Neutrality, Independence, Challenge to Arbitrator ,challenge to judge, Disclosure, legal grounds, Social grounds, Economical grounds,

DOI: $10.7176 / J L P G / 98-17$

Publication date:June 30th 2020

\section{Introduction}

Most of legislations, including the Jordanian legislator, have been confirmed to provide an adequate guarantees to the parties to arbitration, ensuring to improve an arbitration process and its conduct, and from these guarantees is the challenge to his arbitrator, preventing him from the dispute's consideration, in order to enhance the trust of the parties of an arbitration, and achieving its purposes and effects accurately and integrity, as an alternative way Instead of an genuine justice.

The Jordanian legislator in the arbitration law No.31 for a year 2001 and its amendments for a year 2018 an adequate attention of challenge to arbitrator, it has generally studied, meaning that if a serious conditions happen and occur doubts about its neutrality and independence, therefore, the civil trails law included the grounds for challenging to judge and its results in details. from necessary that the judge or arbitrator who is viewing in conflict shall be available neutrality and independence, as well as a full reaching of a social, economic and legal or an emotional relationship which may be effected on his good judge ment decision

The claimant the owner of the interest has a right to request the challenge to arbitrator who has a serious doubts in its neutrality or independence, thus, this right did not leave without organization, therefore, the legislator organized this issue according to the legal, disciplines and procedures followed by the right owner in order to be gaining on his right in challenge to arbitrator in the case of an arbitrator hasn't integrity, neutrality and in an independence in the displayed dispute.

In order to fulfill a requested integrity from an arbitrator as the judge of state, therefore, this study aimed to identify the real grounds of challenge to arbitrator, by dividing these grounds to the legal, social and an economical which it is considered as grounds of challenge to challenge.

\section{Study Significance}

The importance of study shows in detecting a neutrality and independence of an arbitrator which are considered a tow determinations based on the justice of an arbitration , in the case of absence them that may lead to absence justice and it made the real ,judicial and arbitrator credibility in doubt situation, so, neutrality and independence are tow rights from the determined arbitrate opponent to the interest of justice requested, the challenge to arbitrator can't be achieved without a serious conditions occur doubts in an arbitrator neutrality and independence.

\section{Study Problem}

The main problematic issue in this study is being in the grounds challenge to arbitrator in Jordanian arbitration law NO.31 for a year 2001 and its amendments for a year 2018 which they haven't exclusively been as they determined in the Jordanian civil trails law but they are generally determined of flexible statements in the article 17/ffrom the Jordanian arbitration law which is stated if there are a serious conditions occur doubt in its neutrality and 
independence therefore, the legislator added statement seriousness on amendment the arbitration law for a year 2018 and which the researcher to make analysis and examination the serious conditions and grounds that occur the doubts in the neutrality and in dependence of an arbitrator, they were divided to a legal, social and an economical reasons which are considered a grounds challenge to arbitrator and then challenge it .

\section{Study Approach}

The researcher follows in the study the descriptive and analytical approach, by reviewing a legal articles which treat the grounds challenge to arbitrator in the Jordanian arbitration law No.31 for a year 2001 and its amendments for a year 2018 by adding a word the seriousness in the article $17 / 1$ after amend it in order to be....if there are serious conditions occur a doubt in its neutrality and independence and after analyzing the coherent articles in the grounds challenge to arbitrator and stating the issues in determining the grounds challenge to arbitrator and comparing it with the grounds to challenge to judge or stepped down him

Thus, this research states showing what the arbitrator is and its challenge as well as the rules of its appointment in addition to its legal, social and an economical grounds we will divide this study into two topics as follow:

The first topic: what is an arbitrator and his appointments rules the second topic: challenge to arbitrator and social, economical and legal grounds

\section{The first topic \\ The concept of an arbitrator and his appointment rules}

The first requirement: the concept of an arbitrator...

The arbitrator in language: he is the person who is delegated to him by the will of parties are considering to decide mission in the dispute228.

Conventionally: the person who says his technical and legal opinion in the displayed issue by choosing the parties of dispute when it happens or before while

Concluding the same agreement.

There isn't definition in law229, but some jurisprudents defined it as a person who is interesting in the trust of an arbitrator parties whom they granting him an deciding power in issue occurred among them, and the arbitrator can be on person, and it can be numerous when the arbitration board consist of three or five arbitrators 230 .

\section{The second requirement: The arbitrator appointment rules}

The arbitrator is a private and chosen judge from the parties of dispute who shall on them to be in a good ethics of the judge, because it implements a judicial mission toward the opponents where the Jordanian legislator provided in arbitrator a set of rules are:

Firstly: Eligibility of an arbitrator

Secondly: the arbitrator acceptance his mission in written

Thirdly: arbitrator disclosing about any serious conditions occur doubts of his seriousness and independence.

\section{Firstly: Eligibility of an arbitrator}

The legal systems are providing in who appoints an arbitrator to be interesting in full eligibility 231 , and to be ineligible age without any of an eligibility obstacles as it has concluded by the civil law provisions232, according to its personal law233, it shall be available a full civil eligibility in the arbitrator, it is not permissible to minor or quarantine or prohibited from his civil rights because of criminal penalties or bankrupted person to take over the judge ment

Taking over the judgment, the civil eligibility becomes adequate without enjoying in his political rights234.

2- Intermediate index, Part 1, Cairo, 1972, p. 26.

3-The Journal of The Judicial Judgments defined it in the text of article (1790) and considered the arbitrator to be: "The ruler taken by the two opponents with their consent to separate their rivalry and their claims", but this ruler is not the very one who was appointed and appointed by the Sultan, for the dismissal and resolution of the case (1785) of the court of justice, but rather the ruler2 of his two litigants. He is said to be nominated by the Journal of Justice Judgments (Judgment) and (Arbitrator) see Dr. Ahmed Saeed Al-Moumni, Arbitration in Jordanian and Comparative Legislation, Part 1, First Edition, Al-Tawfiq Press, Amman, 1983, p. 211.

4- Dr. Khaled Al-Qadi, The Court's challenge System in Egyptian and Comparative Legislation and International Arbitration Tribunal Systems, Legislative Journal, Legislative Sector at the Ministry of Justice (Egypt), First Year, Third Issue, October, 2004 , p. 71.

5- Dr. Mahmoud Al-Sayyid Al-Tahayi, Arkan agreement on arbitration and the conditions of its validity, p. 618.

6- Jordan Civil law No. (43) of 1976 stipulates that article 43-1 - Any person who reaches the age of majority with mental strength, and has not been quarantined shall be fully qualified to exercise his civil rights.2- The age of majority is eighteen full solar years. Article 44.1- Anyone who has reached the age of majority and who has reached the age of majority and who has reached the age of majority and who has been subjected to incompetence or incompetence shall be considered to be a person who has reached the age of majority and who has reached the age of majority and who has been unconscious or incapacitated, is not eligible to be eligible.

7- Dr. Fawzi Mohammed Sami, (2008), International Commercial Arbitration - Comparative Study of International Commercial Arbitration, First Edition/3rd Edition, House of Culture, Amman, p. 152.

8- A. Hamdi Brik Radwan, Lawyer, (1995) The judgments of the arbitrators and their implementation in the Egyptian law of pleadings, research published in the journal of law, part two, year 74, August, p. 176.. 
The eligibility is defined that is the quality that encloses to the person and basically determined his ability to gain the rights and affording commitments and the legal actions, and power to person in order to direct practicing his civil rights 235 .

The Jordanian legislator confirmed on organizing the rule of an eligibility of arbitrator, in the article 15 from arbitration law the arbitrator shall not minor or quarantined or prohibited from his civil rights because of the judgment of crime or misdemeanor deteriorated o honor or due to showing his bankruptcy even he reconsidered . Through examining the article $15 / 1$ from the Jordanian arbitration law the conditions that shall be available they are requests by the law in the eligibility of an arbitrator and there as follow:

1-Full eligibility:

The arbitrator shall have full civil capacity, by reaching the age of majority. It is advisable to have full capacity in the arbitrator because of the seriousness of his mission, excessive trust in him and the correct authenticity of the wise, i.e., it is not right to arbitrate the minor for any reason 236.

The mission of arbitration needs to be recognized, distinguished and able to balance things.

2- The arbitrator shall not be quarantined:

The arbitrator shall have full mental eligibility, i.e. full eligibility, and do not experience any symptoms of eligibility, such as insanity, dementia, detent or inattention 237.

If any of the symptoms of eligibility occur as a result of insanity or dementia, it is unconscious and discriminatory and may occur to a symptom, leading to an imbalance in its management and vision238, for example, the detent and the inattention, and the specialized court shall quarantine them, and appoint a curator for each of the four cases mentioned earlier to act on them by himself 239 .

It is not legally reasonable for the one who is quarantined to be a arbitrator, because he is forbidden to act on one of his rights, so how can he has the right to act against others 240 .

3- Shall be not sentenced of penalty or criminal or misdemeanor deteriorated of honor:

The legislator has deprived a person who is sentenced to a crime or misdemeanor deteriorated honor because it violates the trust that shall be provided by the arbitrator 241.

Crime,In cases of a court ruling imposing a person, or issuing a penalty for a crime or misdemeanor against him, prohibition of him to be a judge shall not take place until after the ruling is final, i.e. incapable of any of the ordinary methods of appeal, whereas unusual methods

of appeal such as seeking reconsideration, It shall not affect the judgment being final, and

There fore, shall not preclude the consideration of a person who does not meet the legal requirements of the arbitrator.

4-He shall not be sentenced by showing bankruptcy:

The Jordanian legislator stipulated in the arbitration law that who is chosen or appointed an arbitrator should not be sentenced to the month of bankruptcy, and some jurisprudence considers that sentencing a person to the month of bankruptcy for stopping paying his commercial debts leads to a breach of the trust that must be provided by the arbitrator242.

\section{Secondly: the arbitrator accepts his mission in written}

The Jordanian legislator stipulated in who is appointed an arbitrator in any dispute to accept his mission in written and by his signature to accept his mission in written, i.e. writing and, , or by an independent letter, and did not provide a specific model for that, article (15/c) of the Jordanian Arbitration Law No. (31) of 2001 stipulated: "It is the acceptance of the arbitrator to carry out his mission in written".

It should be noted that the providing to accept the arbitrator his mission in written, in order to disclose any circumstances that may occur doubts about his neutrality and independence in the toward any of the dispute, parties, if there are certain circumstances that may not accept the mission of arbitration, except after the parties agreeing to these circumstances and accept them in written, to be an argument and to be in accordance with him in advance, the arbitrator's acceptance of the mission in written from his free will, and is one of the basic principles recognized in the arbitration system.

9- Dr. Ibrahim Ahmed Ibrahim, (1997) Special International Law, (Conflict of Laws), Arab Renaissance House, p. 187.

10- Dr. Nabil Ismail Omar, (2004 AD) Arbitration in National and International Civil and Commercial Articles. P.95

11- Dr. Mohsen Shafiq, (1983) International Commercial Arbitration, (Study in International Trade Law), Arab Renaissance House, Cairo, p. 97. Ipod. Ahmed Abdel Rahman Al-Malham, (1994), research entitled Arbitration Contract between arbitrators and litigants, Rights Magazine, Issue II, p. 45.

12- Advisor Mohamed Ali Skeker, (2006) Arbitration Legislation in Egypt and the Arab Countries, D.M., p. 62.

13- .Article (127) of the Jordanian Civil Code states that:

1 -The little, the madman and the insane are so disinterested in their own right 2-The idiots and an attentions detent by the court"

14.Hamid Al-Allahbi, (2001/2002) Arbitrator in International Commercial Arbitration, First Edition, p. 93.14-

15-Dr. Mustafa Al-Jamal and Dr. Okasha Abdel-Alaal, (1998), Arbitration in International and Internal Special Relations, Part 1, First Edition, Al-Halabi Human Rights Publications, Beirut, p. 607.

17- .Dr. Ahmed Abu al-Wafa,a (2007) Optional and Compulsory Arbitration, University Publications House, Alexandria, Item 66, p. 159. Dr. Mustafa Al-Jamal and Dr. Akasha Abdel-Al, (1999), objective assumptions and subjective conditions in the arbitrator, p. 62. 


\section{Thirdly: The arbitrator discloses any circumstances that occur doubts about his neutrality or independence}

Disclosure means the arbitrator's initiative to inform the parties of his past and current connection to the issue of the dispute and the parties, their representatives and their families243. It is the fundamental obligation that the arbitrator has to do simply to nominate him for the task of arbitration, i.e. an acknowledgement by the arbitrator that there is no impact on his neutrality and independence, and that those circumstances he has revealed do not affect his independence and objectivity 244.

This obligation is a commitment that is a commitment that is closely linked to the essence of the arbitrator's mission and is dictated by the special nature of his mission, how he is appointed and the temporary nature of his powers 245. This was confirmed by the Jordanian legislator in the arbitration law in article 15/c, which states that:

"The arbitrator's acceptance of his or her mission shall be in writing and, upon acceptance, he shall disclose any circumstances that would occur doubts about his neutrality and independence $246 "$ ".

Therefore, the arbitrator's relative to one of the dispute, or to both or their friendship with one of them or being an consultant to one of the parties, is not a grounds for his challenge, as long as these grounds are not unknown to the other party at the time of the arbitrator's selection, or the commitment of arbitration proceedings. If this knowledge is achieved afterwards, this relative or friendship may be a valid ground for challenging if it would affect the independence of the arbitrator alone 247.

The importance of the arbitrator's disclosure is highlighted by the fact that the parties are informed in advance of the circumstances surrounding his work as a judge, and if they do so, his appointment and his judiciary are valid as a rule, and the arbitrator may not be challenged during proceedings, nor by his final judge ment in the need for such circumstances248. It is therefore not unusual for the various modern laws in arbitration, and the rules of different arbitration institutions, to ask the arbitrator accepting his mission (or earlier), to declare any circumstances that would cast doubt on his neutrality and independence 249.

\section{The second topic: the grounds for the arbitrator social, economic and legal The first requirement: the concept of challenge to arbitrator}

The arbitrator's challenge is to forcibly dismiss the arbitrator by judicial decision (or the arbitration institution appointed), at the request of one of the arbitral parties, because of one of the grounds for the challenge 250 .

The challenge to arbitrator is one of the real basic guarantees by many international legislation, including the Jordanian legislator of the parties to the litigants, in order to achieve the justice desired by arbitration, and did not leave the order of the arbitrator to challenge 251.

However, the Jordanian legislator organized the grounds challenge to arbitration law No. 31 for the year 2001 and its amendments 2018 with articles $(20,18,17) 252$, which required that the grounds challenge to arbitrator's in this study be divided into legal, social and economic grounds.

\section{The second requirement: the legal grounds challenge to arbitrator}

The Jordanian legislator has ensured that the parties to the control dispute have an important guarantee of their right to return the arbitrator when the grounds for his challenge are available. The arbitration law did not require special grounds for challenge to arbitrator but left it to the opponents in the grounds on which they were based, and the general rule does not allow the dismissal of the arbitrator appointed by one of the parties, because he was appointed by his own free will, but an exception originally authorized challenge to arbitrator 'if the opponent proved the circumstances that occur doubts about the neutrality and independence of the arbitrator.

18 - Dr. Abu al-Ala Ali Abu Ala (2001), the legal system of the court's challenge. Research published in the Journal of Legal and Economic Sciences, Faculty of Law, Ain Shams University, First Issue, January, p. 218.

19- Dr. Sahar Abdel Sattar, (2006) Legal Center of the Arbitrator/ Comparative Study, Arab Renaissance House, Cairo, p. 189

20- Dr. Huda Mohammed Abdel Rahman, (1997), the role of the arbitrator in the arbitration dispute - and the limits of his powers - Dar alNahda al-Arabiya, Cairo, p. 160.

21- Article (15/c) of the Jordanian Arbitration law states that:

"The arbitrator's acceptance of his or her mission shall be in writing and, upon acceptance, he must disclose any circumstances that would raise doubts about his neutrality and independence." It is matched by article (16/3) of the Egyptian Arbitration law. Article (12/1) of the Palestinian Arbitration law. Article 16 of the Omani Arbitration law. Article 22 of the Tunisian Arbitration law. Article (1452) of the French Law of Pleading. Article (12) of the Model International Commercial Arbitration law.

22- Dr. alqadi, previous reference, p. 74

23- Court of cassation of Kuwait's rights, appeal no. 182, date of March 11, 1987, number 15, p. 179.

24- Dr. haddad, p 224.

25 - Dr. haddad, p 222

26- For more, see Dr. Al-Kharasbheh (2010), Abdul Kareem, p.ss. 141-169

27- This is contrary to what the old Jordanian Arbitration Law (18) of 1953 stated. Article (11) of it stipulated only the court's response, as it was not clear in its text, which stated that it was:" If the arbitrators or the jury misbehaves or intentionally neglect to act under the arbitration agreement after one of the parties has requested it in writing, the court may suspend it and appoint a successor if the appointed team or the arbitrators who appointed it do not do so". 
The Jordanian legislator has followed a different approach between the judge and the arbitrator in terms 253 , of the grounds for their respective challenges:

Firstly: The arbitrator's shall not be disclosed the circumstances that occur doubts about neutrality and independence

The obligation of the Jordanian legislator, when approached by one of the parties to the litigant, to inform him of all circumstances that may affect his opinion, neutrality and independence alone 254, at the moment of their choice255, and the violation of the court's integrity by disclosure, is a ground for his challenge if any of the litigants during the proceedings reveal facts that raise doubts about his neutrality or independence that the arbitrator did not disclose at the time as required by law256, especially the impact of his relationship or sympathy with one of the parties to the dispute 257 .

Article $15 / \mathrm{c}$ of the Jordanian Arbitration law states :

..."In acceptance, he shall disclose any circumstances that would raise doubts about his neutrality and independence. This obligation will continue to be made by the arbitrator if such circumstances exist during the arbitration proceedings".

The court's decision was rejected by the Court of Appeal. Such as the arbitral tribunal being made up of an individual arbitrator, which the parties agreed to appoint258, while one of them knows that the arbitrator is the legal counsel or agent of the other party259, or the board consists of three arbitrators and one of the two opponents was working for the arbitrator who Appointed him, and informed the other party who agreed or did not object to this appointment, despite his knowledge of the circumstance saluting the challenge 260 .

The Jordanian legislator has been consisted with the standard Law for International Commercial Arbitration in disclosing the circumstances that raise doubts about the neutrality and independence of the arbitrator. Article (12/1) states that:

"When approached with the intention of appointing an arbitrator, a person must state all the circumstances that would raise justified doubts about his neutrality and independence ".

This is what the Cairo Regional Arbitration Centre (CSC) has adopted in article (3) of the rules of conduct: "Anyone who is nominated to be an arbitrator must authorize those who contact him in order to do so in all circumstances that may raise justifiable doubts about his neutrality or independence" 261 .

Secondly: The arbitrators shall be abided by the principle of neutrality and independence among the parties to the dispute

Article (17/a) in an amendment to the Jordanian Arbitration law of 2018 stipulates that:

"A. The arbitrator may only be dismissed if there are serious circumstances that raise doubts about his neutrality and independence" 262 .

Some differences 263 , have tended to create dividing features that distinguish between the arbitrator's independence and neutrality. Independence is a rule for the appointment of the arbitrator and for his continuity in the consideration of the dispute until the judge this handed down; The parties264, often raise the issue of both neutrality and independence when objecting to the arbitrator' conduct 265.

28- .Dr. Mahmoud Hashem, (1990) General Theory of Arbitration in Civil and Commercial Materials, Part 1, Arab Thought House, Cairo, p. 209. Dr. Awad al-Zoubi, (2003) Due process of civil trials, first edition, part 1, Wael Publishing House, Amman, p. 99

29- Dr. AL-Jamal,(2001), previous reference, p. 18

30- Dr. Ali Ramadan Barakat, (1996), Arbitration In Egyptian Law and Comparative Law, Arab Renaissance House, Cairo, p. 243.

31- Dr. Abdul Rahman, 1997, previous reference, p. 163

32-The arbitrator has been working to fill out a model in the framework of the International Chamber of Commerce in Paris, in which he affirms his independence from the parties to the litigant, and the absence of links between him and any of them, affecting the composition of his opinion. If any of these circumstances or information are concealed by the chosen arbitrator, it is a reason for his .Dr. Aljamal, 2001, previous reference, p. 6.

33- Discrimination of Lebanon, Room, No. 71/2003, 22 April 2003 (Lebanese Magazine, Issue 27, p. 36). The provision also stated that the reason for responding to a dispute initiated by the claimant to respond with the arbitrator may not be established, with a view to exclude hi from the consideration of the dispute, as this is contrary to the principle of good faith in contracts, which must be committed by the two parties in the implementation of the contract. For more see: Haddad, previous reference, p. 225

34- Court of cassation of Kuwait's rights, Appeal No. 42, 3/6/1981, Issue 6. See: Haddad, previous reference, p. 225

35- previous reference, p. 225.

36- Dr. Mohammed Salim Al-Awa, (2007), Studies in Egyptian and Comparative Arbitration Law, Arab Center for Arbitration, p. 64.

37- It is matched by the text of Article (18/1) of the Egyptian Arbitration law and Article (18/1) of the Omani Arbitration Act. Article 13 of the Palestinian Arbitration law. Article (24/1/a) of the English Arbitration law, which stipulates that the arbitrator shall challenge to the consideration of the dispute if he has circumstances surrounding him may raise doubts about his neutrality, and therefore the latter legislator does not consider the lack of independence of the arbitrator to be a ground for his challenge, as is the case with the Jordanian and Egyptian legislators, who require the arbitrator to be impartial and independent. The Chartered institute of arbitrators, (1998), Handbook of arbitration practice, Sweet \& Maxwell, London,p58.

.Abdul Rahman, 1997, previous reference, p. 102.38

39- Dr. Daoud Shehada Khalaf, (2002) Arbitration In accordance with the Jordanian Arbitration Law No. (31) of 2002, Author, Amman, p. 46 40- Dr. Abdul Rahman, 1997, previous reference, p. 102 
Some argue 266 that there is no distinction in terms of the neutral requirement that must be met in each arbitrator, whether the arbitrator is an individual or the expected arbitrator, and the arbitrator appointed by one of the parties, although this condition makes no sense in the event of the appointment of a single arbitrator by the parties, even if the arbitrator has an interest. In any dispute, as long as the parties have chosen it with conviction and are fully aware of this when agreeing arbitration, the French judiciary has settled on the challenge to arbitrator appointed unilaterally, as is any arbitrator, , the arbitrator is a judge and not an agent of an adversary, even if his appointment is by one of them 267.

\section{Thirdly: The challenge to arbitrator to the same grounds for challenge to judge' and incompetence if he does not disclose it}

The nature of the arbitrator's work during the dispute is a judge of a special kind, and the judges have their own interests and emotions, influenced by them, which may lead to doubts about the neutrality and independence of the arbitrator, and may therefore be dismissed if one of the grounds challenge to judges' challenge268, or for one of the grounds why the judge is not competent under articles $(134,132)$ of the Jordanian Trial Assets Act269, because the reasons for the arbitrator's challenge are similar to the grounds challenge to judge.

The purpose of both of theme's challenge is to remove those who have been suspected of not being neutral or to doubt their integrity, integrity and independence 270 .

The Jordanian legislator did not specify in detail the reasons for the arbitrator to challenge in cases of incompetence and restitution in the case of the judge, and the Court of Cassation of Jordan has argued that the arbitrator as a judge applies to him cases where the judge is not fit to hear the case or is prevented from hearing any challenge 271 .

The old Jordanian Arbitration Law No. (18) of 1953 did not take the court's challenge, but the jurisprudence of the Jordanian Court of Cassation went on to measure the case of the dismissal of the arbitrator if the judge's dismissal and his disqualification from dealing with the adjudication of the dispute and applied to the case of dismissal the sentences applied to the request for the judge's challenge 272 .

If the Syrian legislator has taken a different path from the Jordanian legislator, the grounds to challenge to judge are the same grounds that are suitable for the arbitrator to challenge273.

"The arbitrator may not be dismissed for the grounds given by the judge, or if he has lost one of the rules of his task under this Law."

\section{Fourthly: The arbitrator shall not have agreed qualifications}

Arbitration is free to agree on certain conditions in the arbitrator, such as obtaining a certain scientific qualification or having the head of the arbitral tribunal to have this qualification, as in the FIDIC contracts that require certain qualifications in the arbitrators, such as being a legal, lawyer274 or architect, or having certain experience in the

41- Dr. Najib Ahmed Abdullah al-Jabali, (2006) Arbitration in Arab Laws Comparative Study in Islamic Jurisprudence and Positius Regulations, Modern University Office, Alexandria, p. 274.

42- Paris Appeal, June 8, 1972, Arbitration Journal, 1973, p. 38. The Paris appeal was ruled on March 22, 1983, Arbitration Magazine, 1983, p. 482 .

43- Abu Al-Wafa,a 2007, previous reference, p. 161

44- .Article 132: The judge shall be not fit to hear the case, even if none of the litigants has replied in the following cases:

If he or she is the husband of an adversary or is close or son-in-law to the fourth degree.2- If he or her spouse has an existing rivalry with an adversary or with his spouse. 3 . If he is an agent of an adversary in his own business, guardian, value or belief inherited from him, or is the husband of the guardian of an adversary or value the refore, or it has a relationship or a fourth degree of association with this guardian or curator of a member of the board of directors of the competent company or one of its directors, and this member or director has a personal interest in the case. 4. If he, his spouse, a relative, his or her in-law on the column of descent, or to his agent, guardian or valuables have an interest in the existing case 5- If he or she has a relationship with one of the judges of the Commission, or has a relationship with the defender of an adversary, or a relationship with one of the litigants. For the second degree. 6 - If he has filed or defended one of the litigants in the case, even before his work in the judiciary, or has already been considered by a judge, expert or arbitrator or has testified in it.7 - if he files a compensation claim against the applicant or submits a communication against him in the jurisdiction .Article 134: The judge may challenge to one of the following grounds:

1.If he or her wife has a suit similar to the one he is considering or if one of them has an argument with an adversary or his spouse after the action brought before the judge, unless the case has been initiated with the intention of dismissing the case before him.2. If his divorce has a son, a relative or an in-law or an in-law. On the ratios column, an dispute is in court with one of the litigants in the suit or with his spouse, unless this liability has been established after the judge has filed a complaint with the intention of dismissing it. 3 - If one of the litigants is working with him. 4 - If he or she has used to live with an adversary or has received a gift from him prior to or after the filing of the suit. 5 . If he and an adversary have animosity or affection, he is more likely not to be able to judge without a inclination.

45- Dr. ALjamal, 2006, previous reference, p. 78. Haddad, 2007, previous reference, p. 226

46- Decision to discriminate rights, No. 36/2002, date 6/2/2002, Aladleh publications

47- See the Decision of the Jordanian Court of Cassation No. (130/81), issued on 9/5/1981, The Bar Journal, Issue 9, 1981, p. 1586, and Resolution 29/71 of 20/5/1971, The Lawyers' Syndicate Magazine, Numbers (6.5), 1971, p. 611

49- In addition, we refer to some laws that expressly state that the ground challenge to the arbitrator' are the same grounds for the judge's challenge, including article (22) of the Yemeni Arbitration law No. (22) of 1994 and article (207/4) of the UAE Civil Procedure law of 1992. In the same vein, article 12 of the Saudi arbitration system and article (178/2) of the Kuwaiti law of arguments

50- The arbitrator in England often shall not have legal qualifications, but many arbitration agreements provide for this. See: The Chartered, 
subject of the dispute, and then it becomes clear to them that it is not, in this case, they or one of them may request a challenge 275 .

The Jordanian legislator did not provide in the arbitration law that the arbitrator should challenge in the event that he did not obtain the qualification that the parties to the dispute agreed to require, although it is a ground to challenge to arbitrator in accordance with the standard Law for International Commercial Arbitration, where the frankness of article (12/2) states that276.

"A challenge to arbitrator may only be made if ... Or if he does not have the qualifications agreed upon by the parties ....277"

Third requirement : social grounds challenge to arbitrator challenge

The circumstances or relationships between the arbitrator and one of the parties to the dispute that may raise doubts about the neutrality and independence of the arbitrator and are valid challenge to the court's ] as long as it deliberately conceals these circumstances, i.e. by not disclosing them prior to appointment to an arbitrator, and these circumstances are:

-The existence of family relationships:

During the consideration of the dispute, one of the parties may find that there is a family relationship between the arbitrator and one of the parties to the dispute, i.e. the arbitrator's association with one of the parties to the dispute with relative or relative that leads to a relationship among them 278 .

If the arbitrator has a relationship with one of the parties to the dispute or to the case brought by one of the parties to the dispute and cannot play his role as arbitrator if one of the parties to the dispute has a spouse, son or relatives, then he shall step down from a work immediately, as is the case with judges in the courts279.as the parties appeal court said that the arbitrator shall be not considered married or consultant of one of the parties to be enough to the parties lose a trust in his neutrality.

-The existence of social relations :

The social relations between the arbitrator and one of the parties to the dispute are divided into several cases, including before or after the appointment, and until the end of the dispute to dispute, as follows:

1 exchange of visits between the arbitrator and one of the parties to the dispute .

2. The arbitrator is accustomed to the cohabitation or cohabitation of an adversary.

3. The existence of friendship, enmity or dispute between the arbitrator and one of the parties to the dispute or their relatives 280 .

4. The acceptance of gifts and benefits from one of the liabilities directly or indirectly prior to or after the selection of an arbitrator, article (6) of the Cairo Regional Centre for Commercial Arbitration rules states that:

"The arbitrator may not accept gifts or benefits directly or indirectly from any arbitration parties, and this applies to gifts and subsequent benefits to the arbitration as long as they are associated with it".

\section{Fourth requirement: economic grounds for challenge to arbitrator}

Firstly: Business relationships

The arbitrator's association with an opponent in a working relationship with or employed by a party to a dispute, such as working for an employee or consultant 281.

It has been ruled in the UAE that the consulting engineer in the contracts represents the employer and is considered as his agent in many of the contracting work. Legally, the engineer is not fit to be a judge to decide the dispute between the employer (client) and the contractor in accordance with UAE law282.

previous reference, $\mathrm{p} 45-50$.

51- Consultant Munir Abdel-Magied,(2005) the general basis for international and internal arbitration (in private law, in the light of jurisprudence, and arbitration). Dr. Hamza Haddad, Principles of Commercial Arbitration and the Role of Arbitration Institutions, a working paper presented to the Yemeni Center for Conciliation and Arbitration in the training course on the role of dispute-involved parties and those involved in the arbitration process(17-21/3/2001). www.law.com.jo/research8.htm .

52- This is met by the English legislator, who authorized the arbitrator's reply if he did not have the qualifications required by the parties to the dispute, as stipulated in the English Arbitration law in article $(24 / 1 / \mathrm{b})$ and the text reads as follows :

"That he does not possess the qualifications required by the arbitration agreement."

53- This is in line with what the English legislator stated in his arbitration law of 1996, which was one of the reasons for the arbitrator's challenge if he did not have the competencies and abilities required in the arbitration agreement. See the Chartered, op. cit, p58(

Beauty and Abdul Al, 1998, p. 607.54-

55- The Chartered Institute of Ciudad, previous reference, $\mathrm{p} 44$.

56- One of the cases in which the ICC regulatory body refused to challenge to the arbitrator's response to hostile remarks against the nationality of dispute, and when there is a close link between the arbitrator and one witness, and also when it was found that the president of the arbitral tribunal was acting as vice chairman of the board of directors of a company that holds a project in the state of an adversary. In its judge ment of 15 December 1967, the Paris Court of Appeal also rejected the arbitrator's reply, although he was counsel to an adversary in an earlier arbitration on the basis of the need for material elements to make the link more realistic, indicating the need for an actual bias. See: Abdul Rahman, 1997, previous reference, p. 189

57- Dr. Al-Jamal, Yahiya, (2001) The neutrality and independence of the arbitrators, research published in the Journal of Arab Arbitration, 4th issue, August, p. 15. A. Hussein Al-Momen Lawyer, (1977), Brief in Arbitration, Fajr Press, Beirut, p. 44

58- In one of its rules, the Dubai Court of Cassation rejected the appointment of the consultant engineer as arbitrator in such a dispute, stating 
Secondly: The existence of a business relationship:

A business relationship between the arbitrator and one of the opponents, such as partners in a business interest or accustomed to trading (buying and selling) and a business relationship may include in a business or arbitrator who is a partner or a party to commercial transactions, such as property or securities and investment, with one of the parties.

Thirdly: The arbitrator's previous relationship in the dispute is considering:

The arbitrator's intervention in the dispute in the previous phase before him is generally an influential ground of the neutrality and of the arbitrator, so the reasons for the challenge are consistent if the arbitrator has given an opinion on the subject matter of the dispute or written consultation, or expressed an opinion in the case prematurely 283 .

The UAE and Lebanese legislators considered that one of the grounds challenge to arbitrator is that one of the opponents has not already chosen the arbitrator himself, an arbitrator in another case, otherwise it may be answered by the other dispute 284 .

Fourthly: The arbitrator has an interest in the subject of the dispute he is considering :

The court's interest in the dispute before it would affect its neutrality, such as being a creditor, sponsor or guarantor of one of the parties to the dispute to be dismissed by arbitration, which, in addition, the creditor and guarantor had an interest in supporting the debtor's position.

\section{Conclusion:}

The researcher discussed in this study the concept of the arbitrator and the rules of his appointment and what is the concept of the arbitrator's challenge, as well as the social, economic and legal reasons for the arbitrator challenge in accordance with the Jordanian Arbitration Law No. (31) For 2001 and amendments for 2018 to end in this study to abstract a set of results and recommendations as follows:

\section{Firstly: Results}

The grounds to challenge shall not have an impact when they are available, but shall be raised by the opponents, and if the opponent shall not request challenge to arbitrator, the judge ment in the case is right.

-The Jordanian legislator has followed a different approach between challenge to judge and challenge to arbitrator, as challenge to judge's has been detailed in the Civil trails law, while the grounds challenge to the arbitrator are total and public.

-The Jordanian legislator has obliged to disclose any circumstances that may raise doubts about his independence and neutrality in order to be before the opponents at when elect him, and if any of the opponents in the proceedings reveal facts that raise doubts about his impartiality or independence. It's a grounds challenge to arbitrator to challenge as the law has obliged.

-The Jordanian legislator is convened by the standard International Commercial Arbitration Act (Unstral) that the grounds challenge to the arbitrator were generally based on all circumstances that raise doubts about the neutrality and independence of the arbitrator, and did not identify challenge to arbitrator challenge in the arbitration law, but he left the grounds to challenge absolutely unrestricted.

-The standard International Commercial Arbitration law has expressly stated that it is one of the grounds challenge to arbitrator that he shall not have agreed qualifications among the parties, and Jordanian law has not been cleared of this provision.

\section{Secondly: Recommendations}

We hope that the Jordanian legislator to be followed the example of the Syrian legislator by adding the following paragraph to the article (17/a) of the Jordanian Arbitration law to be as follows :

The challenge to arbitrator shall not be dismissed unless there are serious circumstances that occur doubts on his impartiality and independence, or if he or she loses one of the rules of his power by this law".

The researcher hopes from the Ministry of Justice of Jordan to follow the example of the ministry of justice of Egypt and Palestinian to prepare lists of an authorized arbitrators who have experience, competent and highly trusting to facilitate the mission of justice by appointing arbitrators when it necessary.

The researcher recommends to include a text for the Jordanian legislator considering the arbitrator not obtain on the qualification whether (scientifically or technically) agreed among the arbitration parties as a grounds to

that a dispute with the employer amounted to a dispute with an engineer, and therefore the latter may not be appointed arbitrator in this dispute, as a person may not be both an dispute and a arbitrator. Discrimination Of Dubai, stabbed 355, on 4 January 1988, year 9, p. 34. However, it subsequently reversed its decision by authorizing the appointment of a consultant to adjudicate the dispute between the contractor and the employer. Appeal number (130) for 2001 dated 17/6/2001, number 13, p. 557. The same court also ruled that the court would not rule on the dismissal of the arbitrator (his challenge), unless there were circumstances that raised serious doubts about his neutrality, independence and integrity. Stabbing No. (250), 3/11/2001, Number 12, p. 762 .

59- Abu al-Wafaa, previous reference, p. 164 .

60- Haddad, 2007, previous reference, p. 229 
challenge to the arbitrator's when it violates it.

\section{References}

* Intermediate index,( 1972) Part 1, Cairo,.

* Dr. Ibrahim, Ahmed Ibrahim, (1997) private International Law, (Conflict of Laws), Arab Renaissance House.

* Abu al-Wafaa, Ahmed, (2007), Optional and Compulsory Arbitration, University Press House, Alexandria.

* Dr. Al-Momani, Ahmed Saeed, (1983) Arbitration in Jordanian and Comparative Legislation, Part 1, First Edition, Conciliation Press, Amman.

* Dr. Al-Melham, Ahmed Abdul Rahman, (1994), research entitled Arbitration Contract between arbitrators and litigants, Law Magazine, Second Issue.

* Almomen, Hussein, (1977), the Brief in Arbitration, Al-Fajr Press, Beirut.

* Al-Haddad, Hamza (), Arbitration in Arab Laws, Al-Halabi Human Rights Publications, First Part, First Edition, Beirut.

* Khalaf, Dawud Shehadeh, (2002), Perceptions of arbitration according to the Jordanian Arbitration Law No. (31) For the year, Author, Amman.

* Abdul Sattar, Sahar, (2006), the Arbitrator Legal Center / Comparative Study, Arab Renaissance House, Cairo.

* Lahbi, Hamid (2001/2002) Arbitrator in International Commercial Arbitration, First Edition.

* Radwan, Hamdi Brik attorney, (1995 AD) rulings of arbitrators and their implementation in the Egyptian Code of Procedure, research published in the law firm, part two, seventy-fourth year, August.

* Barakat, Ali Ramadan, (1996), Arbitration litigation in Egyptian law and comparative law, Arab Renaissance House, Cairo.

* Al-Zoubi, Awad, (2003), The Origins of Civil Trials, First Edition, Part One, Wael Publishing House, Amman, M.

* Al-Awa, Salim, (2007), Studies in the Egyptian and Comparative Arbitration Law, Arab Center for Arbitration.

* .Counselor Skeker, Muhammad Ali, (2006) Arbitration Legislation in Egypt and the Arab Countries.

* Dr. Fawzi Muhammad Sami, (2008 AD), International Commercial Arbitration - A Comparative Study of the Provisions of International Commercial Arbitration - First Edition / Third Edition, Dar Al Thaqafa, Amman.

* Dr.Hashem, Mahmoud, (1990), Civil Judiciary, Al-Bustani Press, Cairo, second edition.

* Dr. Al-Tahyawi, Mahmoud Al-Sayed, , Arkan agreement on arbitration and the conditions of its validity.

* Jamal Mustafa. Abdel-Alaal, Okasha, (1998), Arbitration in Private and International Relations, Part One, First Edition, Al-Halabi Human Rights Publications, Beirut.

* Dr. Mustafa Aljammal, Dr. Okasha Abdel-Alaal, (1999), objective assumptions and subjective rules of the arbitrator

* Mohsen Shafiq, (1983) International Commercial Arbitration, (Study in International Trade Law), Arab Renaissance House, Cairo

* Abdul Majeed, Munir, (2005), general foundations of international and internal arbitration (in private law, in the light of jurisprudence, and the arbitration jurisdiction).

* Al-Gabal , Naguib, (2006), Arbitration in Arab Laws, A Comparative Study of Islamic Jurisprudence and Status Systems, Modern University Office, Alexandria

* Abdel-Rahman, Huda, (1997), the role of the arbitrator in arbitration litigation - and the limits of his powers - Arab Renaissance House, Cairo.

* Dr.. Nabil Ismail Omar, (2004 AD) Arbitration in National and International Civil and Commercial Articles, New University House, Alexandria.

* Ali, Abu Al-Ela, (2001), The Legal System for Arbitrator Response, Journal of Legal and Economic Sciences, Faculty of Law, Ain Shams University, First Issue, January.

* Haddad, Hamza, Principles of Commercial Arbitration and the Role of Arbitration Institutions, a working paper presented to the Yemeni Center for Conciliation and Arbitration in the training course on "The role of dispute parties and parties related to the arbitration process", (17-21 / 3/2001). www.law.com.jo/research8.htm.

* Al-Qadi, Khaled, (2004), Arbitrator to challenge System in Egyptian and Comparative Legislation and International Arbitral tribunal Regulations.

* Al-Jamal, Yahya, (2001), The Neutrality and Independence of Arbitrators, Journal of Arab Arbitration, Fourth Issue, August.

* Al-Jamal, Yahya, (2006), dispute and challenge: A Comparative Study between Judges and Arbitrators, 
(Article), The Journal of Arab Arbitration, No. 9, August.

* Al-Kharabsheh, Abdul Kareem, (2010), "The Role of the Judiciary in the challenge to arbitral tribunal and its effect on Jordanian Legislation - A Comparative Study", Unpublished PhD thesis, Department of Legal Studies, Institute of Arab Research and Studies, Cairo.

* The Chartered institute of arbitrators, (1998), Handbook of arbitration practice, Sweet \& Maxwell, London

Laws used in the study:

$\checkmark \quad$ 1. Jordan Civil Procedure Law No. (24) of 1988.

$\checkmark \quad 2$.Jordan Arbitration Law No. (31) For 2001 and its amendments for 2018.

$\checkmark \quad 3$.Jordan's Repealed Arbitration Law No. (18) of 1953.

$\checkmark \quad 4$.English Arbitration law 1996.

$\checkmark \quad 5$.Egyptian Arbitration Law No. (27) of 1994.

$\checkmark \quad 6$.Syrian Arbitration Law No. (4) Of 207.

$\checkmark \quad$ 7. Standard International Commercial Arbitration law.

- Rules Court of Cassation of Jordan

- Rules Court of Cassation.of Egypt

- Cairo Regional Centre for International Commercial Arbitration. 